\title{
Treatment Strategies of Gastric Cancer-Molecular Targets for Anti-angiogenic Therapy: a State-of-the-art Review
}

\author{
Magdalena Tyczyńska ${ }^{1}$ Paweł Kędzierawski ${ }^{2} \cdot K^{2}$ aja Karakuła ${ }^{3} \cdot$ Jacek Januszewski $^{2} \cdot \mathrm{Krzysztof} \mathrm{Kozak}^{1}$. \\ Monika Sitarz ${ }^{4}$. Alicja Forma ${ }^{2}$ (1)
}

Accepted: 14 March 2021 / Published online: 24 March 2021

(c) The Author(s) 2021

\begin{abstract}
Purpose Recent studies have suggested that molecular targets for the anti-angiogenic therapy might constitute a basis for additional therapy in gastric cancer treatment. A vast number of molecules, receptors, pathways, specific interactions, and thus strategies that target gastric cancer angiogenesis specifically have been reported in numerous research articles and clinical trials.

Methods We conducted a systematic literature review of molecularly targeted treatment strategies in gastric cancer on the following databases-PubMed, Google Scholar, and Scopus—on September 20, 2020. Multiple articles and evaluations were searched for studies reporting newly found and promising molecular anti-angiogenic therapy pathways. Eventually, 39 articles regarding the anti-angiogenic therapy in gastric cancer were included in the final analysis.

Results As a consequence of the release of the pro-angiogenic molecules from the tumour cells, gastric cancer presents high angiogenic capability. Therefore, potential schemes for future treatment strategies include the decrease of the process ligands as well as the expression of their receptors. Moreover, the increase in the angiogenic inhibitor levels and direct aim for the inner walls of the endothelial cells appear as a promising therapeutic strategy. Beyond that, angiogenesis process inhibition seems to indirectly exaggerate the effects of chemotherapy in the considered patients.

Conclusions The anti-angiogenic treatment in gastric cancer patients evaluates its significance especially in the early stages of the malignancy. The studies conducted so far show that most of the meaningful angiogenic factors and receptors with the potential molecular pathways should be further evaluated since they could potentially play a substantial role in future therapies.
\end{abstract}

Keywords Gastric cancer · Carcinogenesis · Angiogenesis · Anti-angiogenic therapy · Treatment · Molecular target

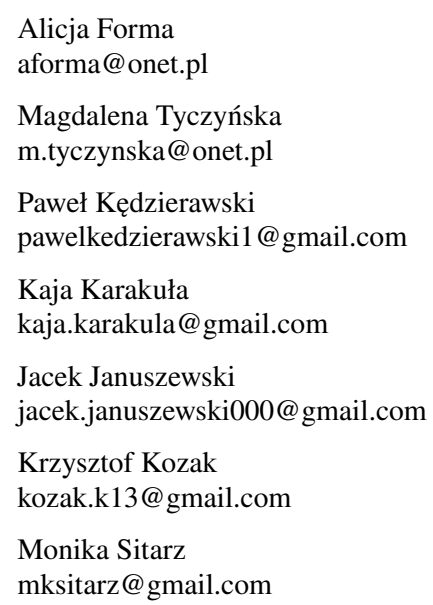

1 Department of Human Anatomy, Medical University of Lublin, 20-090 Lublin, Poland

2 Department of Forensic Medicine, Medical University of Lublin, 20-090 Lublin, Poland

3 Department of Psychiatry, Psychotherapy and Early Intervention, Medical University of Lublin, Gluska Street 1, 20-439 Lublin, Poland

4 Department of Conservative Dentistry with Endodontics, Medical University of Lublin, 20-090 Lublin, Poland 


\section{Introduction}

With more than 990,000 new diagnoses and over 738,000 death cases reported every year, gastric cancer (GC) is estimated to be the fourth most prevalent cancer and currently, it is in the second position in terms of cancer-related deaths [1-3]. The characteristics, as well as the prevalence of GC, significantly differ between sexes and particular world regions. Males are reported to be almost two to three times more susceptible to the onset of GC comparing to females $[4,5]$. The epidemiological studies show that more than $50 \%$ of the newly diagnosed patients are those from developing countries (Eastern Europe, East Asia, Central, and South America); whereas the lower-risk areas include Southern Asia, East Africa, and North America [6]. Besides, the 5-year survival rate of patients also differs depending on the particular region; in Europe, the survival rate is estimated at $10-30 \%$ [7]. Over the last few decades, it was observed that GC incidence rates decreased in most parts of the world. This data, however, concerns only the sporadic intestinal type of GC, whereas the prevalence of the diffuse type of GC has increased $[8,9]$. GC is classified according to two major histological classifications-the Lauren classification and the World Health Organization (WHO) classification [10]. GC might develop due to a vast number of risk factors including enhanced exposition to chemical carcinogens and other environmental factors, family history and genetic predispositions, improper diet, excessive alcohol consumption, or Epstein-Barr virus (EBV) infection; however, the infection by Helicobacter pylori (H. pylori) still remains the major cause of GC induction [11-13]. Several hallmarks of carcinogenesis are crucial in the induction of GC including chronic inflammation, enhanced angiogenesis, or - quite prevalently-the onset of the epithelial-mesenchymal transition (EMT) [14-18].

Carcinogenesis is a multistep process whose progression is highly associated with the angiogenic switch. Angiogenesis is the formation of the new blood vessels from the pre-existing ones and might be either physiological or pathological depending on the conditions (Fig. 1).

Angiogenesis enables cancer cell metastasis, as well as the expansion of the cancerous tissues since the newly formed vessels provide nutrition, proper oxygenation, and supply of the crucial growth factors [19-21]. Pathological angiogenesis is highly uncontrolled due to the dominance of the pro-angiogenic factors [22, 23]. Tumour blood vessels are often inefficient because of the disturbed vascular structure-they tend to form chaotic networks with irregular branching. Furthermore, the blood perfusion through the tumour blood vessels is not continual and bidirectional blood flow might occur [24, 25]. Tumour cells release a significant number of molecules that induce the growth of new vasculature, promoting angiogenesis. Studies have shown that GC cells present a high angiogenic potential; the major pro-angiogenic factors include the vascular endothelial growth factor (VEGF) family with placental growth factor (PIGF) [26, 27],
Fig. 1 Regulation of angiogenesis and vascular homeostasis through the angiogenic activators and inhibitors. EFC-XVendostatin-like fragment of type XV, sFit-1—soluble Fms-like tyrosine kinase 1, PEX-C-terminal hemopexin-like domain, PEDF-pigment epitheliumderived factor, TIMP - tissue inhibitors of matrix metalloproteinases, PIGF-placental growth factor, MMP - metalloproteinases, bFRF-basic fibroblast growth factor, TGF-betatransforming growth factor-beta, TGF-alpha-transforming growth factor-alpha, IGF-1insulin-like growth factor-1, HGF-hepatocyte growth factor, VEGF/VEGFR - vascular endothelial growth factor/vascular endothelial growth factor receptor, IL-8 - interleukin-8, PDGF-platelet-derived growth factor

\section{ANGIOGENIC}

$\begin{array}{llll} & & \\ \text { Collagen fragments } & \text { Prolactin } & \text { INHIBITORS } & \text { Angiopoitin-1 } \\ \text { EFC-XV } & \text { PEX } & \text { PCTIVATORS } & \text { PIFG } \\ \text { Fibulin } & \text { PEDF } & \text { ACTP } \\ \text { Prolactin fragments } & \text { Vasoinhibin } & & \text { bFRF } \\ \text { Platelet factor-4 } & \text { Vasostatin } & \text { TGF-beta } \\ \text { Arresten } & \text { Endostatin } & \text { TFG-alpha } \\ \text { Canstatin } & \text { TIMP } & \text { IGF-1 } \\ \text { Tumstatin } & \text { Angiostatin } & \text { HGF } \\ \text { Thrombospondin 1/2 } & \text { Angioarresein } & \text { VEGF/VEGFR } \\ \text { Endostatin } & \text { Restin } & \text { IL-8 } \\ \text { sFit-1 } & \text { Interferons } & \text { PDGF }\end{array}$

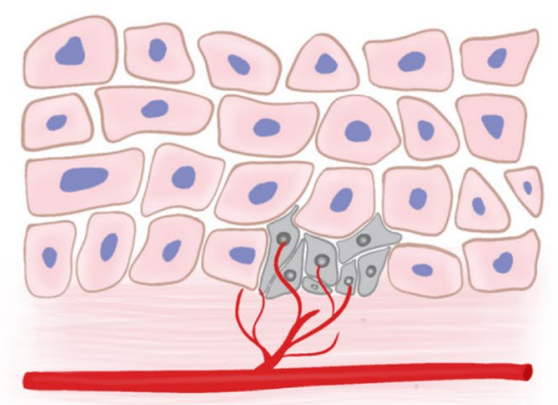

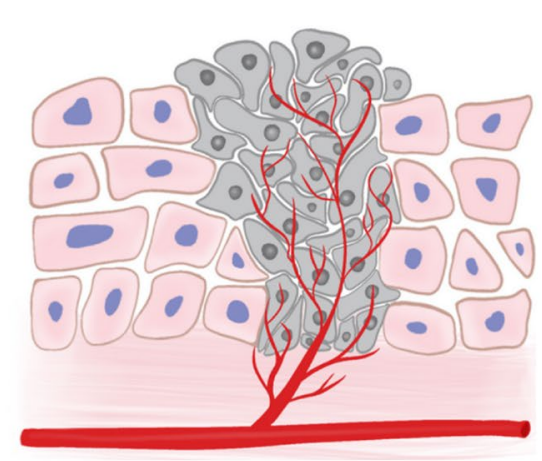


the angiopoietin/Tie-cascade [28], fibroblast growth factors (FGF) [29], hypoxia-inducible factor 1 and 2 (HIF-1 and HIF-2) [30], tryptase [31], and integrins [32, 33].

Currently, there are multiple strategies for GC treatment including a vast number of surgical techniques, chemotherapy, immunotherapy, and targeted therapies including those focused on angiogenesis inhibition for example. The potential strategies of GC treatment include the decrease of the proangiogenic ligands and the expression of their receptors and the increase of the angiogenic inhibitor levels, as well as targeting the inner walls of the endothelial cells (EC) directly [34]. Additionally, the inhibition of the angiogenesis seems to intensify the effects of chemotherapy indirectly, probably because of the vessels' normalization and more effective delivery of the chemotherapeutic agents $[35,36]$. The purpose of this review is to evaluate the significance of the antiangiogenetic treatment in GCs patients, especially in early (perioperative and neoadjuvant) stages of cancer. We summarized the most significant angiogenetic factors and receptors together with potential molecular pathways, their effects, and possible involvement in the anti-angiogenic therapy of GC.

\section{Biomarkers of Angiogenesis}

Since angiogenesis constitutes one of the most crucial hallmarks of carcinogenesis, numerous new therapeutic agents that target this process specifically are currently under investigation. Biomarkers of angiogenesis and their expression provide knowledge about the efficacy of therapy as well as an insight into such aspects as appropriate dose or duration of anti-angiogenic inhibitors. A vast number of those biomarkers are currently used for clinical purposes; however, the aim of further research is to provide an insight into which specific one or which combination might be the most effective in the control of the anti-angiogenic therapy. In this paragraph, we have briefly summarized several most important biomarkers in terms of angiogenesis and further control of the anti-angiogenic therapy.

\section{Vascular Endothelial Growth Factor Family}

VEGF is one of the most significant factors involved in the stimulation of angiogenesis during gastric carcinogenesis [37]. The VEGF family consists of 7 major subtypes including VEGF-A, VEGF-B, VEGF-C, VEGF-D, VEGF-E, VEGF-F, and PIGF [38, 39]. VEGF-A released by the gastric cancer cells is considered to be the major pro-angiogenic factor involved in gastric tumorigenesis [40]. Moreover, the expression of VEGF-A increases the number of vessels in both - the intestinal and the diffuse type of GC [41]. Studies demonstrated a worse overall prognosis in patients with
VEGF-positive tumours compared to the VEGF-negative ones [42].

The binding of VEGF-A to its receptor-VEGFR-2-is considered to be the most crucial activator of the angiogenic pathways [43]. The binding promotes a cascade of signals that result in the proliferation and migration of the ECs, enhanced vascular permeability, modification of gene expression, and activation of the Ras pathway [44, 45]. Contrarily, the role of VEGFR-1 is more intricate and not fully deciphered yet. A soluble form of VEGFR-1 can act as a bait receptor and prevent VEGF-A/VEGFR-2 binding, which inhibits the activation of the signalling pathway. However, there is evidence that VEGFR-1 plays an essential role in the progression of angiogenesis [46]. VEGFR-3 stimulates lymphangiogenesis and does not bind to the VEGF-A [47].

The neuropilins 1 and 2 (NRP1 and NRP2) are involved in the cell guidance and the enhanced binding of VEGF to its signalling receptors [48]. A vast number of other factors present similarity to VEGF-A in terms of the stimulation of the angiogenesis and those include PIGF, FGF, VEGF-C, VEGF-D, angiopoietin, HIF- $1 \alpha$ and HIF- $2 \alpha$, integrins, and PDGF [49, 50].

Overexpression of another member of the VEGF familyPIGF-leads to pathological angiogenesis [51]. Furthermore, it was shown that PIGF overexpression correlates with metastases to lymph nodes, tumour growth, and poor overall survival in GC [52].

\section{Resistin-like Molecule-a}

Resistin-like-molecule- $\alpha$ (RELM- $\alpha$ ) is a protein that plays a significant role in GC progression despite being a marker for anti-inflammatory macrophages [53]. It was reported that RELM- $\alpha$ expression is associated with tumour size and staging [54]. Besides, RELM- $\alpha$ activates the members of the VEGF family by activating the NF-kB-MMP-9/VEGF pathway, enhancing the process of angiogenesis [55]. RELM- $\alpha$ is now considered a new and promising biomarker in GC [5].

\section{Angiopoietins}

During physiological conditions, angiopoietins (Angs) are involved in the embryonic and postnatal angiogenic processes. So far, the most examined members of this family include angiopoietin-1 (Ang-1) and angiopoietin-2 (Ang-2), which are highly overexpressed in gastric cancerous tissues [56]. Ang-1 and Ang- 2 are the ligands for the tyrosine-protein kinase receptor-Tie-2. Ang-1/Tie-2 binding stabilizes the vessels due to the recruitment of the pericytes [57]. On the contrary, Ang-2 antagonizes Tie-2 preventing the maturation of Ang-1, which leads to the suppression of vasculature growth [58]. Furthermore, the disparities between Ang-1 and Ang-2 levels might be associated with the severity of the pro-angiogenic process. 


\section{Platelet-derived Growth Factor- $\beta$ Family}

PDGF- $\beta$ is a crucial component of the tumour progression, as it induces both angiogenesis and EMT, which are highly relevant regarding the alterations within the GC microenvironment [59]. It was shown that PDGF- $\beta$ and VEGF are secreted simultaneously in gastric cancerous tissues, though PDGF- $\beta$ is believed to be more crucial in the maintenance of the blood vessels in the intestinal type of GC [60]. In addition, PDGF- $\beta$ is essential in the migration, proliferation, and adhesion of the endothelial progenitor cells, which are required for both neovascularization and re-endothelialization [61, 62].

\section{Interleukin-8}

IL-8 was originally described as a chemokine whose main role was to attract the polymorphonuclear inflammatory leukocyte infiltrate acting on CXCR1/2 [63]. Recently, it was found that various tumours often overproduce this chemokine, which presents the protumoural characteristics in various malignancies [64]. IL-8 is involved in the angiogenesis, survival signalling for cancer stem cells, and attraction of the myeloid cells, as well as delivery of the local growth factors [65]. Moreover, IL-8 is highly produced by the tumour cells; thus, its serum concentration is significantly associated with tumour growth [66]. Therefore, IL-8 serum concentration is considered to be a useful pharmacodynamic biomarker in the early detection of the immunotherapy response in GC patients [67].

\section{MicroRNA}

MicroRNAs (miRNAs) constitute a group of small, singlestranded, non-coding RNAs that regulate the expression of various genes at the point of post-transcription [68]. Hence, miRNAs are involved in various cellular functions such as proliferation, apoptosis, regulation of embryonic stem cell advancement, and cancer cell invasion [69]. The latest studies have shown that miRNAs are remarkably stable in the blood flow, besides their concentration might present the efficacy of the therapy; this discovery shows that they might be reliable biomarkers of GC therapy [70]. Several studies showed that miRNAs can regulate tumour angiogenesis through targeting both the pro- and antiangiogenic factors, such as RTK signalling protein, HIF, VEGF, and epidermal growth factor (EGF) [71]. miRNA-126 has an essential role in regulating the angiogenesis processes; elevated expression of miRNA-126 is associated with the increased VEGF-A signalling in ECs. Therefore, miRNA is believed to be a promising biomarker of the anti-angiogenic therapy of GC [72, 73].

\section{Circulating Tumour Cells and Free Nucleic Acid}

Circulating tumour cells (CTCs) and free nucleic acid (CTNA) are metastatic cells that are released into the bloodstream by the primary tumour cells; thus, they are involved in the recognition of the hematogenous metastasis [74]. CTCs and CTNA detection in the peripheral blood is a potential strategy for the non-invasive diagnosis and estimation of GC patients' response to treatment therapies [75, 76]. The conducted studies suggest that patients with a low baseline CTC count or drop of the CTC amounts after the first cycle of chemotherapy might substantially benefit from the palliative chemotherapy [77]. Therefore, CTC count might be a good chemotherapy-supervising marker and a prognostic marker for patients receiving palliative chemotherapy [49].

\section{Currently Available Treatment Strategies of Gastric Cancer}

The treatment of GC depends on the type, severity, and stage of $\mathrm{GC}$ - treatment modalities differ in early (EGC) and advanced (AGC) stages of cancer. Nowadays, the most common radical treatment strategy of GC is surgery-gastrectomy [78]. However, there are novel methods that continually become more advanced and more frequently used, such as neoadjuvant chemotherapy, radiotherapy, immunotherapy, and molecularly targeted therapies [78-80].

\section{Surgical Treatment}

The surgical treatment of GC constitutes the major and most frequently used treatment strategy in GC patients; two major types - open and minimally invasive laparoscopic gastrectomies - are distinguished [81, 82]. Laparoscopic gastrectomy can be performed by either the operator or a robot-so-called robotic laparoscopy [81]. The Japanese Gastric Cancer Association distinguishes several types of gastrectomies including total gastrectomy, distal gastrectomy, pylorus-preserving gastrectomy, proximal gastrectomy, segmental gastrectomy, local resection, and non-resectional surgery such as bypass surgery or gastrostomy [82]. Best et al. [83] showed no difference in the short-term mortality rates between laparoscopic and open gastrectomies. The laparoscopic treatment includes the totally laparoscopic distal gastrectomy (TLDG) and the laparoscopic-assisted distal gastrectomy (LADG). Hyui et al. [84] showed that there is no remarkable difference in surgical outcomes and postoperative complications between TLDG and LADG. It was reported that TLDG was preferably chosen due to the lower percentage of postoperative pain and quicker recovery. Surgery treatment also includes the dissection of the lymph nodes [85]. Regional lymph nodes of the stomach are classified into the stations from 1 to 20 plus stations 110 , 
111 , and 112 [86]. The nodal resection as a part of GC treatment can be divided by the D-level criteria depending on the type of gastrectomy $[82,86]$. The extent of lymphadenectomies performed worldwide differs significantly between the countries [87].

\section{Chemotherapy, Adjuvant Chemoradiotherapy, and Neoadjuvant Chemotherapy}

Chemotherapy, as a perioperative treatment, has been improved significantly over the recent years [88]. The survival rate of patients treated with chemotherapy increased compared to patients treated applying the surgical resection alone $[89,90]$. In the case of GC, chemotherapy is preferred in patients with AGC unlike in the case of patients with EGC patients, who are preferred to be treated applying surgical methods [91]. Usually, chemotherapy does not provide a complete cure, however, in the case of patients with unresectable GC, the obtained median survival time was estimated at 6-13 months; adjuvant chemotherapy also seems to be reasonable [82]. Macdonald et al. [92] compared surgical treatment alone versus surgical treatment with fluorouracil and leucovorin treatment combined with radiotherapy. Eventually, the overall survival rate while applying only surgery alone was 26 months, and in investigated adjuvant chemoradiotherapy, it was prolonged up to 36 months [92]. Also, Guimbaud et al. [93] in phase III of their prospective, multicenter, randomized trial compared epirubicin, cisplatin, and capecitabine (ECX) to fluorouracil, leucovorin, and irinotecan (FOLFIRI) as the first-line treatment of AGC and gastroesophageal junction (GEJ). After a median of 31 months, follow-up time-to-treatment failure (TTF) was significantly longer for FOLFIRI in comparison to TTF of ECX (5.1 versus 4.2 months) [93]. The authors announced that FOLFIRI as first-line treatment should be considered as a backbone regiment for targeted treatment agents and, in this case, should be explored [93]. Surgical treatment and dissection of the tumour can cause the activation of the tumour cell growth-stimulating factor and lead to immediate growth of GC tumour. Moreover, it can entail the production of antichemotherapy agents [94]. Thus, the target of neoadjuvant chemotherapy (NAC) is to down-stage tumour and to eliminate potential metastases which can let R0 resection [79]. NAC as a worldwide-accepted treatment was approved by MAGIC randomized trial 903. Terashima et al. [95] in their phase III randomized trial take on targeting the efficiency of NAC considering morbidity, morality, and surgical aspect in stage 3 and stage 4 GC. In their results, there was no major growth of morbidity and mortality registered; however, the time of surgical procedure was significantly shorter (median time equal to 240 and $255 \mathrm{~min}$ for those with and without NAC, respectively) [95].

\section{Radiotherapy}

Radiotherapy is a treatment modality that is frequently combined with chemotherapy in the so-called chemoradiotherapy. After the American SWOG/INT0116 clinical trial, radiotherapy currently constitutes a standard treatment strategy just after the radical gastrectomy in many Oncological Units [96, 97]. However, radiotherapy is also developed as a palliative, first in the 1960s, and adjuvant to neoadjuvant treatment of GC $[78,98]$. Patients with not fully resected tumours are treated palliatively. The recurrent or locally advanced tumour treated by radiotherapy does not give a well-tolerated modality to palliate bleeding, obstruction, or pain, but it is also effective [98]. There are few methods of radiotherapy such as proton beam radiotherapy (PBT) or photon radiotherapy (RT) [98]. There are also some techniques of treatment simulation such as 2-dimensional simulation or 3-dimensional simulation [99, 100]. During the radiation therapy treatment, patients are exposed to 45 to 50.4 Grey (Gy) in total, which can eventually result in serious adverse reactions [78, 101]. Gao et al. [102] showed that intraoperative radiotherapy (OIRT) did not prolong the overall survival of GC patients but instead, and it had favourable effects in stage II and stage III tumours.

\section{Immunotherapy}

Immunotherapy with checkpoint inhibitors is a novel method that has entered the clinical practice as the human immune system can be stimulated to identify the malignant tumours by the immune surveillance and ultimately inhibit the tumour growth [103, 104]. Nowadays, immunotherapy is targeted at the expression of the PD-1 checkpoint receptor ligand, PD-L1, and the tumours with microsatellite instability (MSI-H) [103, 105]. PD-1 is expressed on the activated T-lymphocytes (primarily to the intratumoural antigen-specific CD8+ T lymphocytes), and binds its ligands-PD-L1 and PD-L2-on the tumour cells which leads to exhaustion, anergy, or apoptosis of that lymphocyte and let the growth and development of the tumour [106-110]. Thus, blocking those immune checkpoints stimulates the T lymphocytes against GC cancer cells by avoiding their binding to the ligands [106]. In the USA, the first and only inhibitors approved by the Food and Drug Administration (FDA) in MSI-H tumours are pembrolizumab and nivolumab (primarily used in Japan). Several others are currently investigated in the clinical trials-ramucirumab (phase I), leucovorin (phase II), avelumab (phase III); the last one was accepted by the European Medicines Agency (EMA) [111]. According to Kamath et al. [106], pembrolizumab provided a promising response at about $12-22 \%$ in third-line treatment of locally advanced and metastatic GC. 


\section{Molecularly Targeted Therapy}

Molecularly targeted therapy is a treatment modality that is based on the growth, cell cycle, apoptosis, angiogenesis, and invasion $[78,112,113]$. Main treatment strategies include the epidermal growth factor receptor (EGFR), VEGF, matrix metalloproteinase (MMP), erythroblastic leukemia viral oncogene homolog 2 (HER2 - a member of the EGFR family), and RTK/RAS pathway [78, 80, 114].

EGFR is the receptor whose activation stimulates the intracellular pathways that lead to enhanced proliferation, migration, and angiogenesis. Thus, blocking this receptor inhibits tumour proliferation [78]. There are several agents that block EGFR such as anti-EGFR monoclonal antibodies or EGFR tyrosine kinase inhibitors (EGFR-TKI) [78]. Cetuximab is considered to be a good medicament in the untreated GC [115]. Pinto et al. [115] in their phase II trial compared cetuximab plus docetaxel and cisplatin to docetaxel and cisplatin alone. The rate of response was $41 \%$, and it was higher than in docetaxel and cisplatin alone treatment $[115,116]$.

VEGF belongs to the family of cytokines that regulate angiogenesis [117]. This family consists of 7 main subtypes including VEGF-A, VEGF-B, VEGF-C, VEGF-D, VEGF-E, VEGF-F, and PIGF [118]. There were two clinical phase III trials-REGARD and RAINBOW-both focused on ramucirumab (VEGFR-2 antibody) on previously treated AGC $[119,120]$. However, despite the promising results, those agents do not inhibit the progression of GC; however, they can prolong survival time, unfortunately, only in months [117].

The MMP family consists of few members, inter alia MMP-1, -2, -7, -9, and -12 [78]. MMPs degrade cellular compounds, which in consequence leads to growth, progression, and metastases of the tumour [121]. Marimastat is the MMP inhibitor of the abovementioned MMPs; combined with 5-fluorouracil (5-FU), this drug is considered to be a valuable anticancer treatment strategy [122].

An HER-2 signalling pathway is another way of treatment that is continually investigated and improved [114]. There are few ongoing trials (phase II and III) of trastuzumab: NCT02205047 (INNOVATION)—phase II; NCT01774786 (JACOB)—phase II; and RTOG 1010phase III. Trastuzumab-based therapies are continually improved especially in the case of HER2-positive GCs $[114,123]$.

\section{Anti-angiogenic Therapy-Potential Molecular Targets and Drugs}

Angiogenesis constitutes one of the major processes that enable metastasis of GC cells leading to the growth of the secondary tumours. Therefore, the anti-angiogenic drugs are considered to be potential drugs that might prevent the formation of pathological vessels eventually repressing tumour growth and metastases. Most of the anti-angiogenic drugs primarily target the VEGF pathway since it plays a crucial role in the induction and progression of angiogenesis. It was demonstrated that anti-VEGF tyrosine kinase inhibitors (sunitinib, sorafenib, apatinib, trebananib, and regorafenib) combined with chemotherapy significantly improve the overall survival rates as well as the progression-free survival of patients with advanced GC [124-126]. Generally, the plasma levels of the angiogenic factors such as VEGF or Angs are believed to be associated with the survival rates of GC patients [127]. One of the IgG1 monoclonal antibodies against VEGFR-2, ramucirumab, is currently recommended as the second-line treatment of GC according to the RAINBOW and REGARD trials; besides, a combination of ramucirumab with paclitaxel is also very effective [128-130]. Ramucirumab has been approved by the FDA as the first drug used in patients with advanced GC after the unsuccessful chemotherapy. Except for VEGFs and Angs, other factors such as insulin-like growth factor-1 (IGF-1) are involved in angiogenesis [131]. It was demonstrated that combined treatment that targets VEGF and IGF-R1 at the same time might be promising in GC treatment. Besides, VEGF production might be suppressed while administrating (-)-epigallocatechin-3-gallate (EGCG) either alone or combined with docetaxel [132, 133]. In the HGF-VEGF axis, angiogenesis could thus also be suppressed by the expression of $\mathrm{miR}-26 \mathrm{a} / \mathrm{b}$ [134].

Luteolin is one of the Chinese herbs belonging to the flavonoids which was described to play a role in the inhibition of the tumour cells proliferation and migration as well as suppression of the epithelial-mesenchymal transition (EMT) in the tumour microenvironment [135]. Except that, it was suggested that luteolin might act as a potential suppressor of angiogenesis and the formation of the vasculogenic mimicry tubes by inhibiting the Notch1-VEGF signalling pathway [136]. Another member of the flavonoids, deguelin, inhibits apoptosis and angiogenesis (by targeting VEGF and HIF-1 $\alpha$ ) in the GC microenvironment [137]. Zerumbone, derived from Zingiber zerumbet, was also reported to inhibit angiogenesis by targeting the NF- $\mathrm{KB}$ pathway and eventually downregulating VEGF expression [138]. A member of the plant stress hormones belonging to the jasmonate family - methyl jasmonate exerts anti-tumour properties; it also suppresses VEGF expression in a time-dependent manner primarily due to the downregulation of the metalloproteinase-14 (MMP-14) [139]. Xiaotan Sanjie decoction is widely used in traditional Chinese Medicine, and Shi et al. showed that it might significantly downregulate VEGF-A, VEGFR-1, with VEGFR-2, along with VEGF-A mRNA levels primarily by regulating IL-8 levels [140].

Currently, the first-line treatment of GC includes the administration of 5-fluorouracil (5-FU), and it was suggested that its precursor-capecitabine-similarly to 5-FU might reduce VEGF expression in the GC xenografts [141]. It was observed that the metastatic potential of GC could be potentially 
inhibited by the usage of interleukin-1 receptor antagonist (IL-1RA), which at the same time inhibits the IL-1 $\alpha /$ VEGF signalling pathway lowering VEGF expression and further tube formation [142]. Targeting another pathway associated with angiogenesis by the usage of AT1R antagonist-TCV116 - similarly represses tumour growth by inhibiting angiogenesis [143]. Similar results were obtained while applying recombinant human endostatin; however, in this case, except for inhibiting angiogenesis, also the apoptosis of GC cells was observed [144]. Aminoguanidine, an iNOS-selective inhibitor, and NK4, an HGF antagonist, were also shown to play a role in inhibiting angiogenesis in GC patients [145, 146]. A downregulation of the p-ERK-c-Fos-HIF-1 $\alpha$-VEGF pathway by AZD6244 (selective MAPK-ERK kinase inhibitor) represses further angiogenesis progression according to Gao et al. [147]. The HIF-1 $\alpha$-SIRT1 pathway is also suppressed by forkhead transcription factors of the O class 1 (FOXO1), which inhibits the growth of a gastric tumour and prevents vascularization and overexpression of other angiogenesis-related molecules [148, 149]. Another angiogenesis inhibitor-NM3 - combined with oxymatrine showed to be effective in suppressing the growth of GC cells in in vivo studies [150]. There is an increasing interest in RNA interference (RNAi)-mediated inhibition of such factors as leucine-rich repeat-containing $\mathrm{G}$ protein-coupled receptor 5 (Lgr5), or heparanase which seems to be a promising therapeutic method to abolish gastric angiogenesis $[151,152]$.

\section{Conclusions}

Anti-angiogenic therapy currently constitutes only an additional therapeutic option for patients with the angiogenic phenotype of $\mathrm{GC}$, which might prolong the survival rate of patients as well as increase their quality of life. Even though the anti-angiogenic therapy seems to be favourable and successfully used for clinical purposes, further prospective randomized studies are needed for the evaluation of the potential drugs used as a part of this therapy. One of the therapeutic challenges is a situation when the advanced aggressiveness of GC induces further resistance to anti-angiogenic treatment. Moreover, there is always a risk that multitargeted therapy might constitute a too expensive approach depending on the possibilities of particular medicinal facilities. However, significantly better outcomes are observed in the case of patients that are treated with targeted molecular therapy and anti-angiogenic treatment. Therefore, an increasing number of newly discovered pathways and molecules that interact with one another might enhance the development of new therapeutic agents that can suppress the progression of $\mathrm{GC}$ angiogenesis. There is still further need to examine the potential molecular targets described in this review, especially in clinical trials and prospective randomized studies, especially taking into consideration the patients with different histological and molecular types of GC.
Abbreviations AGC: advanced stage of gastric cancer; Angs: angiopoietins; Ang-1: angiopoietin-1; Ang-2: angiopoietin-2; bFRF: basic fibroblast growth factor; CTCs: circulating tumour cells; CTNA: free nucleic acid; EBV: Epstein-Barr virus; EC: endothelial cells; ECX: epirubicin, cisplatin, and capecitabine; EFC-XV: endostatin-like fragment of type XV; EGC: early stage of gastric cancer; EGCG: epigallocatechin-3-gallate; EGFR: epidermal growth factor receptor; EGFRTKI: EGFR tyrosine kinase inhibitors; EMA: European Medicines Agency; EMT: epithelial-mesenchymal transition; FDA: Food and Drug Administration; FGF: fibroblast growth factors; FOLFIRI: fluorouracil, leucovorin, and irinotecan; FOXO1: forkhead transcription factors of the $\mathrm{O}$ class 1; GC: gastric cancer; GEJ: gastroesophageal junction; Gy: Grey; HER2: erythroblastic leukemia viral oncogene homolog 2; HGF: hepatocyte growth factor; HIF-1: hypoxia-inducible factor 1; HIF-2: hypoxia-inducible factor $2 ; \mathrm{H}$. pylori: Helicobacter pylori; IGF-1: insulin-like growth factor-1; IL-1RA: interleukin-1 receptor antagonist; IL-8: interleukin-8; LADG: laparoscopic-assisted distal gastrectomy; LGR5: leucine-rich repeat-containing G proteincoupled receptor 5; miRNAs: microRNAs; MMP: metalloproteinases; MSI-H: microsatellite instability; NAC: neoadjuvant chemotherapy; NRP1: neuropilin 1; NRP2: neuropilin 2; OIRT: intraoperative radiotherapy; PBT: proton beam radiotherapy; PD-L1: PD-1 checkpoint receptor ligand; PD-L2: PD-2 checkpoint receptor ligand; PDGF: platelet-derived growth factor- $\beta$; PEDF: pigment epithelium-derived factor; PEX: C-terminal hemopexin-like domain; PIGF: placental growth factor; RELM- $\alpha$ : resistin-like-molecule- $\alpha$; RNAi: RNA interference; RT: radiotherapy; sFit-1: soluble Fms-like tyrosine kinase 1; TGFalfa: transforming growth factor-alpha; TGF-beta: transforming growth factor-beta; TIMP: tissue inhibitors of matrix metalloproteinases; TLDG: totally laparoscopic distal gastrectomy; TTF: time-to-treatment failure; VEGF/VEGFR: vascular endothelial growth factor/vascular endothelial growth factor receptor; WHO: World Health Organization; 5-FU: 5-fluorouracil

\section{Declarations}

Conflict of interest The authors declare no competing interests.

Open Access This article is licensed under a Creative Commons Attribution 4.0 International License, which permits use, sharing, adaptation, distribution and reproduction in any medium or format, as long as you give appropriate credit to the original author(s) and the source, provide a link to the Creative Commons licence, and indicate if changes were made. The images or other third party material in this article are included in the article's Creative Commons licence, unless indicated otherwise in a credit line to the material. If material is not included in the article's Creative Commons licence and your intended use is not permitted by statutory regulation or exceeds the permitted use, you will need to obtain permission directly from the copyright holder. To view a copy of this licence, visit http://creativecommons.org/licenses/by/4.0/.

\section{References}

1. Ferlay J, Shin HR, Bray F, Forman D, Mathers C, Parkin DM. Estimates of worldwide burden of cancer in 2008: GLOBOCAN 2008. Int J Cancer. 2010;127(12):2893-917. https://doi.org/10. 1002/ijc. 25516.

2. Edwards BK, Noone AM, Mariotto AB, Simard EP, Boscoe FP, Henley SJ, Jemal A, Cho H, Anderson RN, Kohler BA, Eheman CR, Ward EM. Annual Report to the Nation on the status 
of cancer, 1975-2010, featuring prevalence of comorbidity and impact on survival among persons with lung, colorectal, breast, or prostate cancer. Cancer. 2014;120(9):1290-314. https://doi.org/10. 1002/cncr.28509.

3. Jemal A, Center MM, DeSantis C, Ward EM. Global patterns of cancer incidence and mortality rates and trends. Cancer Epidemiol Biomarkers Prev : a publication of the American Association for Cancer Research, cosponsored by the American Society of Preventive Oncology. 2010;19(8):1893-907. https://doi.org/10.1158/10559965.EPI-10-0437.

4. Sitarz R, Skierucha M, Mielko J, Offerhaus G, Maciejewski R, Polkowski WP. Gastric cancer: epidemiology, prevention, classification, and treatment. Cancer Manag Res. 2018;10:239-48. https://doi.org/10.2147/CMAR.S149619.

5. Machlowska J, Baj J, Sitarz M, Maciejewski R, Sitarz R. Gastric cancer: epidemiology, risk factors, classification, genomic characteristics and treatment strategies. Int J Mol Sci. 2020;21(11):4012. https://doi.org/10.3390/ijms21114012.

6. Matsuda T, Saika K. The 5-year relative survival rate of stomach cancer in the USA, Europe and Japan. Jpn J Clin Oncol. 2013;43(11):1157-8. https://doi.org/10.1093/jjco/hyt166.

7. Ferro A, Peleteiro B, Malvezzi M, Bosetti C, Bertuccio P, Levi F, Negri $\mathrm{E}$, La Vecchia C, \& Lunet N. Worldwide trends in gastric cancer mortality (1980-2011), with predictions to 2015, and incidence by subtype. Eur J Cancer (Oxford, England : 1990). 2014;50(7):1330 1344. https://doi.org/10.1016/j.ejca.2014.01.029.

8. Fan XS, Chen JY, Li CF, Zhang YF, Meng FQ, Wu HY, Feng AN, Huang Q. Differences in HER2 over-expression between proximal and distal gastric cancers in the Chinese population. World J Gastroenterol. 2013;19(21):3316-23. https://doi.org/ 10.3748/wjg.v19.i21.3316.

9. Fléjou JF. Classification OMS 2010 des tumeurs digestives: la quatrième édition [WHO Classification of digestive tumors: the fourth edition]. Annales de pathologie. 2011;31(5 Suppl):S27-31. https://doi.org/10.1016/j.annpat.2011.08.001.

10. Lauren $P$. The two histological main types of gastric carcinoma: diffuse and so-called intestinal-type carcinoma. an attempt at a histo-clinical classification. Acta Pathol Microbiol Scand. 1965;64:31-49. https://doi.org/10.1111/apm.1965.64.1.31.

11. Baj J, Forma A, Sitarz M, Portincasa P, Garruti G, Krasowska D, Maciejewski R. Helicobacter pylori virulence factorsmechanisms of bacterial pathogenicity in the gastric microenvironment. Cells. 2020;10(1):27. https://doi.org/10.3390/ cells 10010027.

12. Machlowska J, Kapusta P, Baj J, Morsink FHM, Wołkow P, Maciejewski R, Offerhaus GJA, Sitarz R. High-throughput sequencing of gastric cancer patients: unravelling genetic predispositions towards an early-onset subtype. Cancers (Basel). 2020;12(7):1981. https://doi.org/10.3390/cancers12071981.

13. Pucułek M, Machlowska J, Wierzbicki R, Baj J, Maciejewski R, Sitarz R. Helicobacter pylori associated factors in the development of gastric cancer with special reference to the early-onset subtype. Oncotarget. 2018;9(57):31146-31162. https://doi.org/ 10.18632/oncotarget.25757.

14. Forma A, Tyczyńska M, Kędzierawski P, Gietka K, Sitarz M. Gastric carcinogenesis: a comprehensive review of the angiogenic pathways. Clin J Gastroenterol. 2020. https://doi.org/10. 1007/s12328-020-01295-1.

15. Baj J, Korona-Głowniak I, Forma A, Maani A, Sitarz E, RahnamaHezavah M, Radzikowska E, Portincasa P. Mechanisms of the epithelial-mesenchymal transition and tumor microenvironment in Helicobacter pylori-induced gastric cancer. Cells. 2020;9(4):1055. https://doi.org/10.3390/cells9041055.

16. Di Ciaula A, Baj J, Garruti G, Celano G, De Angelis M, Wang HH, Di Palo DM, Bonfrate L, Wang DQ, Portincasa P. Liver steatosis, gut-liver axis, microbiome and environmental factors. A never-ending bidirectional cross-talk. J Clin Med. 2020;9(8):2648. https://doi.org/10.3390/jcm9082648.

17. Pucułek M, Baj J, Portincasa $\mathrm{P}$, et al. The morphology and application of stem cells in digestive system surgery. Folia Morphologica 2020.

18. Baj J, Brzozowska K, Forma A, Maani A, Sitarz E, Portincasa P. Immunological aspects of the tumor microenvironment and epithelial-mesenchymal transition in gastric carcinogenesis. Int $\mathbf{J}$ Mol Sci. 2020;21(7):2544. https://doi.org/10.3390/ijms21072544.

19. Folkman J. Tumor angiogenesis: therapeutic implications. N Engl J Med. 1971;285(21):1182-6. https://doi.org/10.1056/ NEJM197111182852108

20. Saaristo A, Karpanen T, Alitalo K. Mechanisms of angiogenesis and their use in the inhibition of tumor growth and metastasis. Oncogene. 2000;19(53):6122-9. https://doi.org/10.1038/sj.onc. 1203969.

21. Hoff PM, Machado KK. Role of angiogenesis in the pathogenesis of cancer. Cancer Treat Rev. 2012;38(7):825-33. https:// doi.org/10.1016/j.ctrv.2012.04.006.

22. Yadav L, Puri N, Rastogi V, Satpute P, Sharma V. Tumour angiogenesis and angiogenic inhibitors: a review. Journal of clinical and diagnostic research : JCDR. 2015;9(6):XE01XE05. https://doi.org/10.7860/JCDR/2015/12016.6135.

23. Loizzi V, Del Vecchio V, Gargano G, De Liso M, Kardashi A, Naglieri E, Resta L, Cicinelli E, Cormio G. Biological pathways involved in tumor angiogenesis and bevacizumab based anti-angiogenic therapy with special references to ovarian cancer. Int J Mol Sci. 2017;18(9):1967. https://doi.org/10.3390/ ijms18091967.

24. Nagy JA, Chang SH, Shih SC, Dvorak AM, Dvorak HF. Heterogeneity of the tumor vasculature. Semin Thromb Hemost. 2010;36(3):321-31. https://doi.org/10.1055/s-0030-1253454.

25. Ziyad S, Iruela-Arispe ML. Molecular mechanisms of tumor angiogenesis. Genes Cancer. 2011;2(12):1085-96. https://doi. org/10.1177/1947601911432334.

26. Autiero M, Luttun A, Tjwa M, Carmeliet P. Placental growth factor and its receptor, vascular endothelial growth factor receptor-1: novel targets for stimulation of ischemic tissue revascularization and inhibition of angiogenic and inflammatory disorders. J Thromb Haemost : JTH. 2003;1(7):1356-70. https://doi.org/10.1046/j.1538-7836.2003.00263.x.

27. Villarejo-Campos P, Padilla-Valverde D, Martin RM, MenéndezSánchez P, Cubo-Cintas T, Bondia-Navarro JA, Fernández JM. Serum VEGF and VEGF-C values before surgery and after postoperative treatment in gastric cancer. Clinical \& translational oncology : official publication of the Federation of Spanish Oncology Societies and of the National Cancer Institute of Mexico. 2013;15(4):265-70. https://doi.org/10.1007/ s12094-012-0908-x.

28. Wang J, Wu KC, Zhang DX, Fan DM. Antisense angiopoietin-1 inhibits tumorigenesis and angiogenesis of gastric cancer. World J Gastroenterol. 2006;12(15):2450-4. https://doi.org/10. 3748/wjg.v12.i15.2450.

29. Liang G, Liu Z, Wu J, Cai Y, Li X. Anticancer molecules targeting fibroblast growth factor receptors. Trends Pharmacol Sci. 2012;33(10):531-41. https://doi.org/10.1016/j.tips. 2012.07.001.

30. Stoeltzing O, McCarty MF, Wey JS, Fan F, Liu W, Belcheva A, Bucana CD, Semenza GL, Ellis LM. Role of hypoxia-inducible factor 1alpha in gastric cancer cell growth, angiogenesis, and vessel maturation. J Natl Cancer Inst. 2004;96(12):946-56.

31. Ammendola M, Sacco R, Zuccalà V, Luposella M, Patruno R, Gadaleta P, Zizzo N, Gadaleta CD, De Sarro G, Sammarco G, Oltean M, Ranieri G. Mast cells density positive to tryptase correlate with microvascular density in both primary gastric cancer tissue and loco-regional lymph node metastases from 
patients that have undergone radical surgery. Int J Mol Sci. 2016;17(11):1905. https://doi.org/10.3390/ijms17111905.

32. Zhong B, Wang K, Xu H, Kong F. Silencing Formin-like 2 inhibits growth and metastasis of gastric cancer cells through suppressing internalization of integrins. Cancer Cell Int. 2018;18:79. https://doi.org/10.1186/s12935-018-0576-1.

33. Wang X, Zhou Q, Yu Z, Wu X, Chen X, Li J, Li C, Yan M, Zhu Z, Liu B, Su L. Cancer-associated fibroblast-derived Lumican promotes gastric cancer progression via the integrin $\beta 1$-FAK signaling pathway. Int J Cancer. 2017;141(5):998-1010. https://doi.org/10.1002/ijc.30801.

34. Zecchin A, Kalucka J, Dubois C, Carmeliet P. How endothelial cells adapt their metabolism to form vessels in tumors. Front Immunol. 2017;8:1750. https://doi.org/10.3389/fimmu.2017. 01750 .

35. Nienhüser H, Schmidt T. Angiogenesis and anti-angiogenic therapy in gastric cancer. Int J Mol Sci. 2017;19(1):43. https:// doi.org/10.3390/ijms19010043.

36. Hsieh HL, Tsai MM. Tumor progression-dependent angiogenesis in gastric cancer and its potential application. World J Gastrointest Oncol. 2019;11(9):686-704. https://doi.org/10.4251/wjgo. v11.i9.686.

37. Macedo F, Ladeira K, Longatto-Filho A, Martins SF. Gastric cancer and angiogenesis: is VEGF a useful biomarker to assess progression and remission? J Gastric Cancer. 2017;17(1):1-10. https://doi.org/10.5230/jgc.2017.17.e1.

38. Brown LF, Berse B, Jackman RW, Tognazzi K, Manseau EJ, Senger DR, Dvorak HF. Expression of vascular permeability factor (vascular endothelial growth factor) and its receptors in adenocarcinomas of the gastrointestinal tract. Cancer Res. 1993;53(19):4727-35.

39. Liu W, Dong Z, Hu R, Wang C. Association of vascular endothelial growth factor (VEGF) gene polymorphisms with gastric cancer and its development, prognosis, and survival. Technol Cancer Res Treat. 2018; 17:1533034617753810.

40. Maeda K, Chung YS, Ogawa Y, Takatsuka S, Kang SM, Ogawa M, Sawada T, Sowa M. Prognostic value of vascular endothelial growth factor expression in gastric carcinoma. Cancer. 1996;77(5):858-63. https://doi.org/10.1002/(sici)1097-0142(19960301)77:5\%3c858:: aid-cncr8\%3e3.0.co;2-a.

41. Takahashi Y, Cleary KR, Mai M, Kitadai Y, Bucana CD, Ellis LM. Significance of vessel count and vascular endothelial growth factor and its receptor (KDR) in intestinal-type gastric cancer. Clin Cancer Res : an official journal of the American Association for Cancer Research. 1996;2(10):1679-84.

42. Pang L, Wang J, Fan Y, Xu R, Bai Y, Bai L. Correlations of TNM staging and lymph node metastasis of gastric cancer with MRI features and VEGF expression. Cancer biomarkers : section A of Disease markers. 2018;23(1):53-9. https://doi.org/10.3233/ CBM-181287.

43. Zhang X, Tang J, Zhi X, Xie K, Wang W, Li Z, Zhu Y, Yang L, $\mathrm{Xu} \mathrm{H}, \mathrm{Xu} \mathrm{Z}$. Correction: miR-874 functions as a tumor suppressor by inhibiting angiogenesis through STAT3/VEGF-A pathway in gastric cancer. Oncotarget. 2017;8(17):29535. https://doi.org/ 10.18632/oncotarget.17402.

44. Takahashi T, Ueno H, Shibuya M. VEGF activates protein kinase C-dependent, but Ras-independent Raf-MEK-MAP kinase pathway for DNA synthesis in primary endothelial cells. Oncogene. 1999;18(13):2221-30. https://doi.org/10.1038/sj.onc.1202527.

45. Matsuoka T, Yashiro M. Biomarkers of gastric cancer: current topics and future perspective. World J Gastroenterol. 2018;24(26):2818-32. https://doi.org/10.3748/wjg.v24.i26.2818.

46. Cao Y. (2009). Positive and negative modulation of angiogenesis by VEGFR1 ligands. Science signaling, 2(59), re1. https://doi. org/10.1126/scisignal.259re1.
47. Meadows KN, Bryant P, Pumiglia K. Vascular endothelial growth factor induction of the angiogenic phenotype requires Ras activation. J Biol Chem. 2001;276(52):49289-98. https://doi.org/10. 1074/jbc.M108069200.

48. Soker S, Takashima S, Miao HQ, Neufeld G, Klagsbrun M. Neuropilin-1 is expressed by endothelial and tumor cells as an isoform-specific receptor for vascular endothelial growth factor. Cell. 1998;92(6):735-45. https://doi.org/10.1016/s00928674(00)81402-6.

49. Aktaş SH, Akbulut Yazici HO, Zengin N, Akgün HN, Üstüner Z, Içli F. A new angiogenesis prognostic index with VEGFA, PIGF, and angiopoietin 1 predicts survival in patients with advanced gastric cancer. Turk J Med Sci. 2017;47(2):399-406. https://doi. org/10.3906/sag-1509-80.

50. Benedito R, Rocha SF, Woeste M, Zamykal M, Radtke F, Casanovas O, Duarte A, Pytowski B, Adams RH. Notch-dependent VEGFR3 upregulation allows angiogenesis without VEGF-VEGFR2 signalling. Nature. 2012;484(7392):110-4. https://doi.org/10.1038/nature10908.

51. Chen CN, Hsieh FJ, Cheng YM, Cheng WF, Su YN, Chang KJ, Lee $\mathrm{PH}$. The significance of placenta growth factor in angiogenesis and clinical outcome of human gastric cancer. Cancer Lett. 2004;213(1):73-82. https://doi.org/10.1016/j.canlet.2004.05.020.

52. Mahmoodi F, Akrami H. PlGF knockdown decreases tumorigenicity and stemness properties of spheroid body cells derived from gastric cancer cells. J Cell Biochem. 2017;118(4):851-9. https://doi.org/10.1002/jcb.25762.

53. Pikarsky E, Porat RM, Stein I, Abramovitch R, Amit S, Kasem S, Gutkovich-Pyest E, Urieli-Shoval S, Galun E, Ben-Neriah Y. NF-kappaB functions as a tumour promoter in inflammationassociated cancer. Nature. 2004;431(7007):461-6. https://doi. org/10.1038/nature02924.

54. Chen P, Zhao D, Wang W, Zhang Y, Yuan Y, Wang L, Wu Y. High expression of RELM- $\alpha$ correlates with poor prognosis and promotes angiogenesis in gastric cancer. Oncol Rep. 2015;34(1):77-86. https://doi.org/10.3892/or.2015.3943.

55. Yin Y, Si X, Gao Y, Gao L, Wang J. The nuclear factor- $\kappa B$ correlates with increased expression of interleukin- 6 and promotes progression of gastric carcinoma. Oncol Rep. 2013;29(1):34-8. https://doi.org/10.3892/or.2012.2089.

56. Wang J, Wu K, Zhang D, Tang H, Xie H, Hong L, Pan Y, Lan $\mathrm{M}, \mathrm{Hu}$ S, Ning X, Fan D. Expressions and clinical significances of angiopoietin-1, -2 and Tie2 in human gastric cancer. Biochem Biophys Res Commun. 2005;337(1):386-93. https://doi.org/10. 1016/j.bbrc.2005.09.051.

57. Davis S, Aldrich TH, Jones PF, Acheson A, Compton DL, Jain V, Ryan TE, Bruno J, Radziejewski C, Maisonpierre PC, Yancopoulos GD. Isolation of angiopoietin-1, a ligand for the TIE2 receptor, by secretion-trap expression cloning. Cell. 1996;87(7):1161-9. https:// doi.org/10.1016/s0092-8674(00)81812-7.

58. Sato TN, Tozawa Y, Deutsch U, Wolburg-Buchholz K, Fujiwara Y, Gendron-Maguire M, Gridley T, Wolburg H, Risau W, Qin Y. Distinct roles of the receptor tyrosine kinases Tie-1 and Tie-2 in blood vessel formation. Nature. $1995 \mathrm{Jul}$ 6;376(6535):70-4. https://doi.org/10.1038/376070a0. PMID: 7596437.

59. Maisonpierre PC, Suri C, Jones PF, Bartunkova S, Wiegand SJ, Radziejewski C, Compton D, McClain J, Aldrich TH, Papadopoulos N, Daly TJ, Davis S, Sato TN, Yancopoulos GD. Angiopoietin-2, a natural antagonist for Tie2 that disrupts in vivo angiogenesis. Science (New York, N.Y.). 1997;277(5322): 55-60. https://doi.org/10.1126/science.277.5322.55.

60. Guo Y, Yin J, Zha L, Wang Z. Clinicopathological significance of platelet-derived growth factor B, platelet-derived growth factor receptor- $\beta$, and E-cadherin expression in gastric carcinoma. Contemp Oncol (Poznan, Poland). 2013;17(2):150-5. https://doi.org/ 10.5114/wo.2013.34618. 
61. Suzuki S, Dobashi Y, Hatakeyama Y, Tajiri R, Fujimura T, Heldin $\mathrm{CH}$, Ooi A. Clinicopathological significance of plateletderived growth factor (PDGF)-B and vascular endothelial growth factor-A expression, PDGF receptor- $\beta$ phosphorylation, and microvessel density in gastric cancer. BMC cancer. 2010;10:659. https://doi.org/10.1186/1471-2407-10-659.

62. Zhao Y, Adjei AA. Targeting angiogenesis in cancer therapy: moving beyond vascular endothelial growth factor. The oncologist. 2015;20(6):660-73. https://doi.org/10.1634/theoncologist.2014-0465.

63. Kotyza J. Interleukin-8 (CXCL8) in tumor associated nonvascular extracellular fluids: its diagnostic and prognostic values. A review. Int J Biol Markers. 2012;27(3), 169-178. https://doi. org/10.5301/JBM.2012.9261.

64. Wang X, Yang F, Xu G, Zhong S. The roles of IL-6, IL-8 and IL-10 gene polymorphisms in gastric cancer: a meta-analysis. Cytokine. 2018;111:230-6. https://doi.org/10.1016/j.cyto.2018.08.024.

65. Liu Y, Xu Y, Wang Y, Yao Y, Yang J. Associations between interleukin gene polymorphisms and the risk of gastric cancer: a meta-analysis. Clin Exp Pharmacol Physiol. 2018;45(12):123644. https://doi.org/10.1111/1440-1681.13021.

66. Alfaro C, Sanmamed MF, Rodríguez-Ruiz ME, Teijeira Á, Oñate C, González Á, Ponz M, Schalper KA, Pérez-Gracia JL, Melero I. Interleukin-8 in cancer pathogenesis, treatment and follow-up. Cancer Treat Rev. 2017;60:24-31. https://doi.org/10.1016/j.ctrv. 2017.08.004

67. Murukesh N, Dive C, Jayson GC. Biomarkers of angiogenesis and their role in the development of VEGF inhibitors. Br J Cancer. 2010;102(1):8-18. https://doi.org/10.1038/sj.bjc.6605483.

68. Irmak-Yazicioglu MB. Mechanisms of microRNA deregulation and microRNA targets in gastric cancer. Oncol Res Treat. 2016;39(3):136-9. https://doi.org/10.1159/000443224.

69. Stiegelbauer V, Perakis S, Deutsch A, Ling H, Gerger A, Pichler M. MicroRNAs as novel predictive biomarkers and therapeutic targets in colorectal cancer. World J Gastroenterol. 2014;20(33):11727-35. https://doi.org/10.3748/wjg.v20.i33. 11727.

70. Shin VY, Chu KM. MiRNA as potential biomarkers and therapeutic targets for gastric cancer. World J Gastroenterol. 2014;20(30):10432-9. https://doi.org/10.3748/wjg.v20.i30. 10432.

71. Zhang Z, Li Z, Li Y, Zang A. MicroRNA and signaling pathways in gastric cancer. Cancer Gene Ther. 2014;21(8):305-16. https:// doi.org/10.1038/cgt.2014.37.

72. Wu HH, Lin WC, Tsai KW. Advances in molecular biomarkers for gastric cancer: miRNAs as emerging novel cancer markers. Expert Rev Mol Med. 2014;16:e1. https://doi.org/10.1017/erm. 2013.16.

73. Chen H, Li L, Wang S, Lei Y, Ge Q, Lv N, Zhou X, Chen C. Reduced miR-126 expression facilitates angiogenesis of gastric cancer through its regulation on VEGF-A. Oncotarget. 2014;5(23):1187311885. https://doi.org/10.18632/oncotarget.2662.

74. Lee MW, Kim GH, Jeon HK, Park SJ. Clinical application of circulating tumor cells in gastric cancer. Gut Liver. 2019;13(4):394401. https://doi.org/10.5009/gnl18484.

75. Thanh Huong P, Gurshaney S, Thanh Binh N, Gia Pham A, Hoang Nguyen H, Thanh Nguyen X, Pham-The H, Tran PT, Truong Vu K, Xuan Duong N, Pelucchi C, La Vecchia C, Boffetta P, Nguyen HD, Luu HN. Emerging role of circulating tumor cells in gastric cancer. Cancers. 2020;12(3):695. https:// doi.org/10.3390/cancers12030695.

76. Zheng X, Fan L, Zhou P, Ma H, Huang S, Yu D, Zhao L, Yang S, Liu J, Huang A, Cai C, Dai X, Zhang T. Detection of circulating tumor cells and circulating tumor microemboli in gastric cancer. Transl Oncol. 2017;10(3):431-441, SSN 1936-5233. https://doi.org/10.1016/j.tranon.2017.02.007(http://www. sciencedirect.com/science/article/pii/S1936523316302765)
77. Liu Y, Ling Y, Qi Q, Lan F, Zhu M, Zhang Y, Zhang C. Prognostic value of circulating tumor cells in advanced gastric cancer patients receiving chemotherapy. Mol Clin Oncol. 2017;6:23542. https://doi.org/10.3892/mco.2017.1125.

78. Song Z, Wu Y, Yang J, Yang D, Fang X. Progress in the treatment of advanced gastric cancer. Tumour Biol. 2017;39(7):1010428317714626. https://doi.org/10.1177/ 1010428317714626.

79. Zhou J, Shen J, Seifer BJ, Jiang S, Wang J, Xiong H, Xie L, Wang L, Sui X. Approaches and genetic determinants in predicting response to neoadjuvant chemotherapy in locally advanced gastric cancer. Oncotarget. 2017;8(18):30477-30494. https://doi. org/10.18632/oncotarget.12955.

80. Pellino A, Riello E, Nappo F, Brignola S, Murgioni S, Djaballah SA, Lonardi S, Zagonel V, Rugge M, Loupakis F, Fassan M. Targeted therapies in metastatic gastric cancer: current knowledge and future perspectives. World J Gastroenterol. 2019;25(38):577388. https://doi.org/10.3748/wjg.v25.i38.5773.

81. Qiu H, Ai JH, Shi J, Shan RF, Yu DJ. Effectiveness and safety of robotic versus traditional laparoscopic gastrectomy for gastric cancer: an updated systematic review and meta-analysis. J Cancer Res Ther. 2019;15(7):1450-63. https://doi.org/10.4103/jcrt. JCRT_798_18.

82. Japanese Gastric Cancer Association. (2017) Japanese gastric cancer treatment guidelines 2014 (ver. 4). Gastric Cancer, 20(1):1-19. https:// doi.org/10.1007/s10120-016-0622-4.

83. Best LM, Mughal M, Gurusamy KS. Laparoscopic versus open gastrectomy for gastric cancer. Cochrane Database Syst Rev. 2016;3(3):CD011389. https://doi.org/10.1002/14651858.CD011389. pub2.

84. Jin HE, Kim MS, Lee CM, Park JH, Choi CI, Lee HH, Min JS, Jee YS, Oh J, Chae H, Choi SI, Lee YT, Kim JH, Huang H, Park S. Meta-analysis and systematic review on laparoscopic-assisted distal gastrectomy (LADG) and totally laparoscopic distal gastrectomy (TLDG) for gastric cancer: Preliminary study for a multicenter prospective KLASS07 trial. Eur J Surg Oncol. 2019;45(12):2231-40. https://doi.org/10.1016/j.ejso.2019.06.030.

85. Degiuli M, De Manzoni G, Di Leo A, D’Ugo D, Galasso E, Marrelli D, Petrioli R, Polom K, Roviello F, Santullo F, Morino M. Gastric cancer: current status of lymph node dissection. World J Gastroenterol. 2016;22(10):2875-93. https://doi.org/ 10.3748/wjg.v22.i10.2875.

86. Degiuli M, De Manzoni G, Di Leo A, et al. Gastric cancer: current status of lymph node dissection. World J Gastroenterol. 2016;22(10):2875-93. https://doi.org/10.3748/wjg.v22.i10.2875.

87. Schmidt B, Yoon SS. D1 versus D2 lymphadenectomy for gastric cancer. J Surg Oncol. 2013;107(3):259-64. https://doi.org/10. $1002 /$ jso. 23127.

88. Lam S, Tan E, Menezes A, et al. A comparison of the operative outcomes of D1 and D2 gastrectomy performed at a single Western center with multiple surgeons: a retrospective analysis with propensity score matching. World J Surg Oncol. 2018;16(1):136. https:// doi.org/10.1186/s12957-018-1422-6.

89. Cunningham D, Allum WH, Stenning SP, Thompson JN, Van de Velde CJ, Nicolson M, Scarffe JH, Lofts FJ, Falk SJ, Iveson TJ, Smith DB, Langley RE, Verma M, Weeden S, Chua YJ, Trial MAGIC, Participants. . Perioperative chemotherapy versus surgery alone for resectable gastroesophageal cancer. N Engl J Med. 2006;355(1):11-20. https://doi.org/10.1056/NEJMoa055531.

90. Reddavid R, Sofia S, Chiaro P, et al. Neoadjuvant chemotherapy for gastric cancer. Is it a must or a fake? World J Gastroenterol. 2018;24(2):274-289. https://doi.org/10.3748/wjg.v24.i2.274.

91. Kanat O, O'Neil BH. Metastatic gastric cancer treatment: a little slow but worthy progress. Med Oncol. 2013;30(1):464. https:// doi.org/10.1007/s12032-013-0464-4. 
92. Macdonald JS, Smalley SR, Benedetti J, Hundahl SA, Estes NC, Stemmermann GN, Haller DG, Ajani JA, Gunderson LL, Jessup JM, Martenson JA. Chemoradiotherapy after surgery compared with surgery alone for adenocarcinoma of the stomach or gastroesophageal junction. N Engl J Med. 2001;345(10):725-30. https://doi.org/10.1056/NEJMoa010187.

93. Guimbaud R, Louvet C, Ries P, Ychou M, Maillard E, André T, Gornet JM, Aparicio T, Nguyen S, Azzedine A, Etienne PL, Boucher E, Rebischung C, Hammel P, Rougier P, Bedenne L, Bouché O. Prospective, randomized, multicenter, phase III study of fluorouracil, leucovorin, and irinotecan versus epirubicin, cisplatin, and capecitabine in advanced gastric adenocarcinoma: a French intergroup (Fédération Francophone de Cancérologie Digestive, Fédération Nationale des Centres de Lutte Contre le Cancer, and Groupe Coopérateur Multidisciplinaire en Oncologie) study. J Clin Oncol. 2014;32(31):3520-6. https://doi.org/10.1200/JCO.2013.54.1011.

94. Chen Y, Guo ZQ, Shi CM, Zhou ZF, Ye YB, Chen Q. Efficacy of adjuvant chemotherapy combined with immunotherapy with cytokine-induced killer cells for gastric cancer after $\mathrm{d} 2$ gastrectomy. Int J Clin Exp Med. 2015;8(5):7728-36.

95. Terashima M, Iwasaki Y, Mizusawa J, Katayama H, Nakamura K, Katai H, Yoshikawa T, Ito Y, Kaji M, Kimura Y, Hirao M, Yamada M, Kurita A, Takagi M, Boku N, Sano T, Sasako M. Stomach Cancer Study Group, Japan Clinical Oncology Group. Randomized phase III trial of gastrectomy with or without neoadjuvant S-1 plus cisplatin for type 4 or large type 3 gastric cancer, the short-term safety and surgical results: Japan Clinical Oncology Group Study (JCOG0501). Gastric Cancer. 2019;22(5):1044-52. https://doi.org/10.1007/ s10120-019-00941-z.

96. Ciepiela I, Kędzierawski P, Florek A, Góźdź S, Mężyk R. (2010) The efficacy and the tolerance of postoperative radiochemotherapy in gastric cancer. Contemporary Medicine. 2010;3:217-222. https:// doi.org/10.5114/wo.2010.14133.

97. Spych M, Serbiak B, Rychter A, Jesien-Lewandowicz E, Gottwald L, Fijuth J. Post-operative radiochemotherapy in patients with gastric cancer: one department's experience of 56 patients. $\mathrm{Br}$ J Radiol. 2011 May;84(1001):457-63. https://doi.org/10.1259/ bjr/25406515. Epub 2011 Feb 8. PMID: 21304007; PMCID: PMC3473659.

98. Verma V, Lin SH, Simone CB 2nd, Mehta MP. Clinical outcomes and toxicities of proton radiotherapy for gastrointestinal neoplasms: a systematic review. J Gastrointest Oncol. 2016;7(4):644-64. https:// doi.org/10.21037/jgo.2016.05.06.

99. Lee JA, Lim DH, Park W, Ahn YC, Huh SJ. Radiation therapy for gastric cancer bleeding. Tumori. 2009;95(6):726-30.

100. Hashimoto K, Mayahara H, Takashima A, Nakajima TE, Kato K, Hamaguchi T, Ito Y, Yamada Y, Kagami Y, Itami J, Shimada Y. Palliative radiation therapy for hemorrhage of unresectable gastric cancer: a single institute experience. J Cancer Res Clin Oncol. 2009;135(8):1117-23. https://doi.org/10.1007/ s00432-009-0553-0.

101. Martin-Romano P, Sola JJ, Diaz-Gonzalez JA, Chopitea A, Iragorri Y, Martínez-Regueira F, Ponz-Sarvise M, Arbea L, Subtil JC, Cano D, Ceniceros L, Legaspi J, Hernandez JL, Rodríguez J. Role of histological regression grade after two neoadjuvant approaches with or without radiotherapy in locally advanced gastric cancer. Br J Cancer. 2016;115(6):655-63. https://doi.org/10. 1038/bjc.2016.252.

102. Gao P, Tsai C, Yang Y, Xu Y, Zhang C, Zhang C, Wang L, Liu $\mathrm{H}$, Wang $\mathrm{Z}$. Intraoperative radiotherapy in gastric and esophageal cancer: meta-analysis of long-term outcomes and complications. Minerva Med. 2017;108(1):74-83. https://doi.org/10.23736/ S0026-4806.16.04628-0.
103. Vrána D, Matzenauer M, Neoral Č́, Aujeský R, Vrba R, Melichar B, Rušarová N, Bartoušková M, Jankowski J. From tumor immunology to immunotherapy in gastric and esophageal cancer. Int $\mathrm{J}$ Mol Sci. 2018;20(1):13. https://doi.org/10.3390/ijms20010013.

104. Cai XY, Wang XF, Li J, Dong JN, Liu JQ, Li NP, Yun B, Xia RL, Qin J, Sun YH. High expression of CD39 in gastric cancer reduces patient outcome following radical resection. Oncol Lett. 2016;12(5):4080-4086. https://doi.org/10.3892/ol.2016.5189.

105. De Mello RA, Lordick F, Muro K, Janjigian YY. Current and future aspects of immunotherapy for esophageal and gastric malignancies. Am Soc Clin Oncol Educ Book. 2019;39:237-47. https://doi.org/10.1200/EDBK_236699.

106. Coutzac $\mathrm{C}$, Pernot $\mathrm{S}$, Chaput $\mathrm{N}$, Zaanan A. Immunotherapy in advanced gastric cancer, is it the future? Crit Rev Oncol Hematol. 2019;133:25-32. https://doi.org/10.1016/j.critrevonc.2018.10.007.

107. Ahmadzadeh M, Johnson LA, Heemskerk B, Wunderlich JR, Dudley ME, White DE, Rosenberg SA. Tumor antigen-specific CD8 T cells infiltrating the tumor express high levels of PD-1 and are functionally impaired. Blood. 2009;114(8):1537-44. https://doi.org/10.1182/blood-2008-12-195792.

108. Barber DL, Wherry EJ, Masopust D, Zhu B, Allison JP, Sharpe AH, Freeman GJ, Ahmed R. Restoring function in exhausted CD8 T cells during chronic viral infection. Nature. 2005;439(7077):682-7. https://doi.org/10.1038/nature04444.

109. Goldberg MV, Maris CH, Hipkiss EL, Flies AS, Zhen L, Tuder RM, Grosso JF, Harris TJ, Getnet D, Whartenby KA, Brockstedt DG, Dubensky TW Jr, Chen L, Pardoll DM, Drake CG. Role of PD-1 and its ligand, B7-H1, in early fate decisions of CD8 T cells. Blood. 2007;110(1):186-92. https://doi.org/10.1182/ blood-2006-12-062422.

110. Deng R, Cassady K, Li X, Yao S, Zhang M, Racine J, Lin J, Chen L, Zeng D. B7H1/CD80 interaction augments PD-1-dependent T cell apoptosis and ameliorates graft-versus-host disease. J Immunol. 2015;194(2):560-74. https://doi.org/10.4049/jimmunol. 1402157.

111. Kamath SD, Kalyan A, Benson AB 3rd. Pembrolizumab for the treatment of gastric cancer. Expert Rev Anticancer Ther. 2018;18(12):1177-87. https://doi.org/10.1080/14737140.2018. 1526084.

112. Wu Y, Li Z, Zhang C, Yu K, Teng Z, Zheng G, Wang S, Liu Y, Cui L, Yu X. CD44 family proteins in gastric cancer: a meta-analysis and narrative review. Int J Clin Exp Med. 2015;8(3):3595-606.

113. Huang J, Yang Y, Yang J, Li X. Regenerating gene family member 4 promotes growth and migration of gastric cancer through protein kinase B pathway. Int J Clin Exp Med. 2014;7(9):3037-44.

114. Gerson JN, Skariah S, Denlinger CS, Astsaturov I. Perspectives of HER2-targeting in gastric and esophageal cancer. Expert Opin Investig Drugs. 2017;26(5):531-40. https://doi.org/10.1080/ 13543784.2017.1315406.

115. Pinto C, Di Fabio F, Barone C, Siena S, Falcone A, Cascinu S, Rojas Llimpe FL, Stella G, Schinzari G, Artale S, Mutri V, Giaquinta S, Giannetta L, Bardelli A, Martoni AA. Phase II study of cetuximab in combination with cisplatin and docetaxel in patients with untreated advanced gastric or gastro-oesophageal junction adenocarcinoma (DOCETUX study). Br J Cancer. 2009;101(8):1261-8. https://doi.org/10.1038/sj.bjc.6605319.

116. Lordick F, Luber B, Lorenzen S, Hegewisch-Becker S, Folprecht G, Wöll E, Decker T, Endlicher E, Röthling N, Schuster T, Keller G, Fend F, Peschel C. Cetuximab plus oxaliplatin/ leucovorin/5-fluorouracil in first-line metastatic gastric cancer: a phase II study of the Arbeitsgemeinschaft Internistische Onkologie (AIO). Br J Cancer. 2010;102(3):500-5. https://doi. org/10.1038/sj.bjc.6605521. 
117. Nienhüser H, Schmidt T. Angiogenesis and anti-angiogenic therapy in gastric cancer. Int J Mol Sci. 2017;19(1):43. https:// doi.org/10.3390/ijms19010043.

118. Macedo F, Ladeira K, Longatto-Filho A, Martins SF. Gastric cancer and angiogenesis: is VEGF a useful biomarker to assess progression and remission? J Gastric Cancer. 2017;17(1):1-10. https://doi.org/10.5230/jgc.2017.17.e1.

119. Fuchs CS, Tomasek J, Yong CJ, Dumitru F, Passalacqua R, Goswami C, Safran H, Dos Santos LV, Aprile G, Ferry DR, Melichar B, Tehfe M, Topuzov E, Zalcberg JR, Chau I, Campbell W, Sivanandan C, Pikiel J, Koshiji M, Hsu Y, Liepa AM, Gao L, Schwartz JD, Tabernero J. Trial REGARD, Investigators. Ramucirumab monotherapy for previously treated advanced gastric or gastrooesophageal junction adenocarcinoma (REGARD): an international, randomised, multicentre, placebo-controlled, phase 3 trial. Lancet. 2013;383(9911):31-9. https://doi.org/10.1016/S01406736(13)61719-5.

120. Wilke H, Muro K, Van Cutsem E, Oh SC, Bodoky G, Shimada Y, Hironaka S, Sugimoto N, Lipatov O, Kim TY, Cunningham D, Rougier P, Komatsu Y, Ajani J, Emig M, Carlesi R, Ferry D, Chandrawansa K, Schwartz JD, Ohtsu A. RAINBOW Study Group. Ramucirumab plus paclitaxel versus placebo plus paclitaxel in patients with previously treated advanced gastric or gastro-oesophageal junction adenocarcinoma (RAINBOW): a double-blind, randomised phase 3 trial. Lancet Oncol. 2014;15(11):1224-35. https://doi.org/10.1016/S1470-2045(14) 70420-6.

121. Peng $Z$, Zhang Y. Propofol inhibits proliferation and accelerates apoptosis of human gastric cancer cells by regulation of microRNA-451 and MMP-2 expression. Genet Mol Res. 2016;15(2). https://doi.org/10.4238/gmr.15027078.

122. Bramhall SR, Hallissey MT, Whiting J, Scholefield J, Tierney G, Stuart RC, Hawkins RE, McCulloch P, Maughan T, Brown PD, Baillet M, Fielding JW. Marimastat as maintenance therapy for patients with advanced gastric cancer: a randomised trial. $\mathrm{Br}$ J Cancer. 2002;86(12):1864-70. https://doi.org/10.1038/sj.bjc. 6600310.

123. Shitara K, Yatabe Y, Matsuo K, Sugano M, Kondo C, Takahari D, Ura T, Tajika M, Ito S, Muro K. Prognosis of patients with advanced gastric cancer by HER2 status and trastuzumab treatment. Gastric Cancer. 2013;16(2):261-7. https://doi.org/10.1007/ s10120-012-0179-9.

124. Yu J, Zhang Y, Leung LH, Liu L, Yang F, Yao X. Efficacy and safety of angiogenesis inhibitors in advanced gastric cancer: a systematic review and meta-analysis. J Hematol Oncol. 2016;9(1):111. https://doi.org/10.1186/s13045-016-0340-8.

125. Mawalla B, Yuan X, Luo X, Chalya PL. Treatment outcome of anti-angiogenesis through VEGF-pathway in the management of gastric cancer: a systematic review of phase II and III clinical trials. BMC Res Notes. 2018;11(1):21. https://doi.org/10.1186/ s13104-018-3137-8.

126. Hironaka S. Anti-angiogenic therapies for gastric cancer. Asia Pac J Clin Oncol. 2019;15(4):208-17. https://doi.org/10.1111/ ajco.13174.

127. Aktaş SH, Akbulut Yazici HO, Zengin N, Akgün HN, Üstüner Z, Içli F. A new angiogenesis prognostic index with VEGFA, PIGF, and angiopoietin 1 predicts survival in patients with advanced gastric cancer. Turk J Med Sci. 2017;47(2):399-406. https://doi. org/10.3906/sag-1509-80.

128. Roviello G, Petrioli R, Marano L, Polom K, Marrelli D, Perrella A, Roviello F. Angiogenesis inhibitors in gastric and gastroesophageal junction cancer. Gastric Cancer. 2016;19(1):31-41. https://doi.org/10.1007/s10120-015-0537-5.

129. Obermannová $R$, Lordick $F$. Insights into next developments in advanced gastric cancer. Curr Opin Oncol. 2016;28(4):367-75. https://doi.org/10.1097/CCO.0000000000000289.
130. Javle M, Smyth EC, Chau I. Ramucirumab: successfully targeting angiogenesis in gastric cancer. Clin Cancer Res. 2014;20(23):587581. https://doi.org/10.1158/1078-0432.CCR-14-1071.

131. Li H, Adachi Y, Yamamoto H, Min Y, Ohashi H, Ii M, Arimura Y, Endo T, Lee CT, Carbone DP, Imai K, Shinomura Y. Insulinlike growth factor-I receptor blockade reduces tumor angiogenesis and enhances the effects of bevacizumab for a human gastric cancer cell line, MKN45. Cancer. 2011;117(14):3135-47. https:// doi.org/10.1002/cncr.25893.

132. Zhu BH, Zhan WH, Li ZR, Wang Z, He YL, Peng JS, Cai SR, Ma JP, Zhang CH. (-)-Epigallocatechin-3-gallate inhibits growth of gastric cancer by reducing VEGF production and angiogenesis. World J Gastroenterol. 2007;13(8):1162-9. https://doi.org/10.3748/wjg.v13.i8.1162.

133. Wu H, Xin Y, Xiao Y, Zhao J. Low-dose docetaxel combined with (-)-epigallocatechin-3-gallate inhibits angiogenesis and tumor growth in nude mice with gastric cancer xenografts. Cancer Biother Radiopharm. 2012;27(3):204-9. https://doi. org/10.1089/cbr.2011.1103.

134. Si Y, Zhang H, Ning T, Bai M, Wang Y, Yang H, Wang X, Li J, Ying G, Ba Y. miR-26a/b inhibit tumor growth and angiogenesis by targeting the HGF-VEGF axis in gastric carcinoma. Cell Physiol Biochem. 2017;42(4):1670-83. https://doi.org/10. 1159/000479412.

135. Kozak J, Forma A, Czeczelewski M, Kozyra P, Sitarz E, Radzikowska-Büchner E, Sitarz M, Baj J. Inhibition or reversal of the epithelial-mesenchymal transition in gastric cancer: pharmacological approaches. Int J Mol Sci. 2020;22(1):277. https://doi.org/10.3390/ijms22010277.

136. Zang M, Hu L, Zhang B, Zhu Z, Li J, Zhu Z, Yan M, Liu B. Luteolin suppresses angiogenesis and vasculogenic mimicry formation through inhibiting Notch1-VEGF signaling in gastric cancer. Biochem Biophys Res Commun. 2017;490(3):913-9. https://doi.org/10.1016/j.bbrc.2017.06.140.

137. Lee H, Lee JH, Jung KH, Hong SS. Deguelin promotes apoptosis and inhibits angiogenesis of gastric cancer. Oncol Rep. 2010;24(4):957-63. https://doi.org/10.3892/or.2010.957.

138. Tsuboi K, Matsuo Y, Shamoto T, Shibata T, Koide S, Morimoto M, Guha S, Sung B, Aggarwal BB, Takahashi H, Takeyama H. Zerumbone inhibits tumor angiogenesis via NF- $\mathrm{BB}$ in gastric cancer. Oncol Rep. 2014;31(1):57-64. https://doi.org/10.3892/or.2013.2842.

139. Zheng L, Li D, Xiang X, Tong L, Qi M, Pu J, Huang K, Tong Q. Methyl jasmonate abolishes the migration, invasion and angiogenesis of gastric cancer cells through down-regulation of matrix metalloproteinase 14. BMC Cancer. 2013;13:74. https:// doi.org/10.1186/1471-2407-13-74.

140. Shi J, Lu Y, Wei P. Xiaotan Sanjie decoction inhibits angiogenesis in gastric cancer through Interleukin-8-linked regulation of the vascular endothelial growth factor pathway. J Ethnopharmacol. 2016;189:230-7. https://doi.org/10.1016/j.jep.2016.05.043.

141. Yuan F, Shi H, Ji J, Cai Q, Chen X, Yu Y, Liu B, Zhu Z, Zhang J. Capecitabine metronomic chemotherapy inhibits the proliferation of gastric cancer cells through anti-angiogenesis. Oncol Rep. 2015;33(4):1753-62. https://doi.org/10.3892/or.2015.3765.

142. Gong Z, Ma J, Su H, Guo T, Cai H, Chen Q, Zhao X, Qi J, Du J. Interleukin-1 receptor antagonist inhibits angiogenesis in gastric cancer. Int J Clin Oncol. 2018;23(4):659-70. https://doi.org/10. 1007/s10147-018-1242-2.

143. Huang W, Wu YL, Zhong J, Jiang FX, Tian XL, Yu LF. Angiotensin II type 1 receptor antagonist suppress angiogenesis and growth of gastric cancer xenografts. Dig Dis Sci. 2008;53(5):1206-10. https://doi.org/10.1007/s10620-007-0009-9.

144. Li DN, Wang L, Wang L, Li S, Wang YB. Expression of inhibitor of differentiation-1 and its effects on angiogenesis in gastric cancer. Cancer Biother Radiopharm. 2016;31(7):233-7. https:// doi.org/10.1089/cbr.2016.2043. 
145. Wang GY, Ji B, Wang X, Gu JH. Anti-cancer effect of iNOS inhibitor and its correlation with angiogenesis in gastric cancer. World J Gastroenterol. 2005;11(25):3830-3. https://doi.org/10. 3748/wjg.v11.i25.3830.

146. Heideman DA, van Beusechem VW, Bloemena E, Snijders PJ, Craanen ME, Offerhaus GJ, Derksen PW, de Bruin M, Witlox MA, Molenaar B, Meijer CJ, Gerritsen WR. Suppression of tumor growth, invasion and angiogenesis of human gastric cancer by adenovirus-mediated expression of NK4. J Gene Med. 2004;6(3):317-27. https://doi.org/10.1002/jgm.523.

147. Gao JH, Wang CH, Tong H, Wen SL, Huang ZY, Tang CW. Targeting inhibition of extracellular signal-regulated kinase kinase pathway with AZD6244 (ARRY-142886) suppresses growth and angiogenesis of gastric cancer. Sci Rep. 2015;5:16382. https:// doi.org/10.1038/srep16382.

148. Kim SY, Ko YS, Park J, Choi Y, Park JW, Kim Y, Pyo JS, Yoo YB, Lee JS, Lee BL. Forkhead transcription factor FOXO1 inhibits angiogenesis in gastric cancer in relation to SIRT1. Cancer Res Treat. 2016;48(1):345-54. https://doi.org/10.4143/crt.2014. 247.

149. Kim SY, Yoon J, Ko YS, Chang MS, Park JW, Lee HE, Kim MA, Kim JH, Kim WH, Lee BL. Constitutive phosphorylation of the FOXO1 transcription factor in gastric cancer cells correlates with microvessel area and the expressions of angiogenesis-related molecules. BMC Cancer. 2011;11:264. https://doi.org/10.1186/ 1471-2407-11-264.

150. Song MQ, Zhu JS, Chen JL, Wang L, Da W, Zhu L, Zhang WP. Synergistic effect of oxymatrine and angiogenesis inhibitor NM-3 on modulating apoptosis in human gastric cancer cells. World J Gastroenterol. 2007;13(12):1788-93. https://doi.org/10. 3748/wjg.v13.i12.1788.

151. Xi HQ, Zhang KC, Li JY, Cui JX, Gao YH, Wei B, Huang D, Chen L. RNAi-mediated inhibition of Lgr5 leads to decreased angiogenesis in gastric cancer. Oncotarget. 2017;8(19):3158131591. https://doi.org/10.18632/oncotarget.15770.

152. Zheng L, Jiang G, Mei H, Pu J, Dong J, Hou X, Tong Q. Small RNA interference-mediated gene silencing of heparanase abolishes the invasion, metastasis and angiogenesis of gastric cancer cells. BMC Cancer. 2010;10:33. https://doi.org/10.1186/ 1471-2407-10-33.

Publisher's Note Springer Nature remains neutral with regard to jurisdictional claims in published maps and institutional affiliations. 